\title{
Promoting Scholarship and Faculty Development through Faculty Learning Communities
}

Olive J. Yonge Dr.

University of Alberta, oyonge@ualberta.ca

Sandra J. Davidson

University of Alberta, sandra.davidson@ucalgary.ca

Follow this and additional works at: https://qane-afi.casn.ca/journal

Part of the Educational Leadership Commons, Other Nursing Commons, and the Scholarship of Teaching and Learning Commons

\section{Recommended Citation}

Yonge, Olive J. Dr. and Davidson, Sandra J. (2017) "Promoting Scholarship and Faculty Development through Faculty Learning Communities," Quality Advancement in Nursing Education - Avancées en formation infirmière: Vol. 3: Iss. 2, Article 5.

DOI: https://doi.org/10.17483/2368-6669.1120

This Article is brought to you for free and open access by Quality Advancement in Nursing Education - Avancées en formation infirmière. It has been accepted for inclusion in Quality Advancement in Nursing Education - Avancées en formation infirmière by an authorized editor of Quality Advancement in Nursing Education - Avancées en formation infirmière. 


\section{Promoting Scholarship and Faculty Development through Faculty Learning Communities}

\section{Cover Page Footnote}

Acknowledgments Grace Miazga and Samantha Marks, Teaching Assistants and participants of the Faculty Learning Communities Funded by the Vargo Teaching Chair Awarded to Olive Yonge. Nos remerciements à Grace Miazga et Samantha Marks, assistantes à l'enseignement et participantes aux Communautés apprenantes du corps professoral financées par le prix Vargo Teaching Chair remis à Olive Yonge. 
Nursing is a profession and, as such, members have an obligation to engage in professional development. This article describes one method of faculty development: faculty learning communities (FLCs). A FLC was originally defined as a group of faculty "who engage in an active, collaborative, yearlong program with a curriculum about enhancing teaching and learning... the scholarship of teaching and community building" (Cox \& Richlin, 2004, p. 8). Later in 2013, Cox referred to FLCs as communities of practice (CoP). Wenger, McDermott, and Snyder (2002), considered the pioneers of CoPs, define FLCs as groups of people who share a concern or passion for something they do and want to refine their work by meeting with other faculty regularly. The aim of a FLC is to transform a higher education institution into a learning organization through a collaborative approach to teaching and learning scholarship (Cox \& Richlin, 2004; Senge, 1990).

The purpose of this article is to describe what FLCs are and how we implemented FLCs in our faculty of nursing $(\mathrm{FoN})$.

\section{Significance}

All faculty, regardless of rank, position, motivation, or teaching abilities, require professional development in the areas of teaching and learning. As professionals, they are expected to provide high-quality education to students. Given the dynamic and ever-changing nature of higher educational institutions, faculty are expected to keep abreast of advances in technology, such as game-based learning, and innovations like teaching in the flipped classroom, and engage students who seem to prefer their hand-held mobile devices rather than listening to the professor during class time (Kuznekoff \& Titsworth, 2013).

Faculty need a sense of belonging (Davidson, 2011). They need to understand the culture of the faculty and how they can make a contribution. Furco and Moely (2012) note faculty must first feel safe and supported before they can engage in open, honest discussions. An underlying goal of many FLCs is to mitigate faculty stress. There are occurrences whereby faculty may feel overwhelmed, underappreciated, or simply lost in their role as an educator (Davidson, 2011). Their family may not understand the nature of the stress the way that another faculty member will. FLCs provide an opportunity for faculty to feel more connected to their colleagues and establish collegial supportive relationships.

\section{Review of the Literature}

FLCs fall in the broad area of professional faculty development. The philosophical underpinnings stem from educational philosophers such as John Dewey (1916) who believed "an ounce of experience is better than a ton of theory because it is only in experience that any theory has vital and certifiable significance" (p. 144). Dewey characterizes experiences as either active (undertaking an activity) or passive (undergoing the consequences). Learning and growth take place through the cycle of reflecting and drawing on past experiences. In the absence of this cycle, an experience is merely an activity. Participants in a FLC actively gain new knowledge by having the opportunity to ask questions, receive feedback, and engage in critical dialogues about their teaching (Bond, 2015). In doing so, they become re-energized and gain confidence (Anderson et al., 2014; O'Meara, 2007). They also leave the FLC better informed and equipped to manage faculty work (Wicks, Craft, Mason, Gritter, \& Bolding, 2015).

Cox (2013) began offering FLCs in 1979 at Miami University of Ohio. He initially

focused on early-career academics who later in mid-career flourished in the area of teaching and 
learning. Cox then began to offer FLCs to late-stage academics, and they too benefited. He found professors who were in FLCs, regardless of the stage of career, had a greater understanding of the scholarship of teaching and learning and a stronger affiliation with their institution. Whether research focused on adjunct faculty (Bond, 2015; Brydes et al., 2012) or tenured faculty (Gordon \& Foutz, 2015), most researchers cite the work of Cox and Richlin in the review of the literature. A search of the nursing education literature yielded no mention of FLCs, yet they are ideally suited to the nature of nursing faculty whose members strive to improve their teaching and learning.

\section{Description of FLCs}

Cox and Richlin (2004) regard FLCs as either cohort-based or topic-based. Cohort-based FLCs are comprised of members sharing the same level of employment within the institution; their topics emerge from the issues common to the cohort. Topic-based FLCs are formed according to prevalent issues amongst faculty, regardless of employment level. Faculty members submit various FLC proposals to a program director, who selects the topics to be covered. Both cohort- and topic-based groups have a facilitator who emphasizes inclusivity, team support, and the need for beneficial outcomes. Membership is voluntary, thereby fostering personal investment in the community process and collective output (Cox \& Richlin, 2004).

Qualities that help create a sense of community within FLCs are safety, trust, openness, respect, responsiveness, collaboration, relevance, challenge, enjoyment, esprit de corps, and empowerment (Cox, 2004; Banasik \& Dean, 2016). These qualities are promoted through effective facilitation and engagement among the FLC participants. Unlike committees or seminars, a FLC forms according to a commonality of scholarly interests or concerns and sets out tangible goals from its outset, thereby promoting scholarly growth and participation amongst members (Cox, 2013). The FLC model emphasizes participant autonomy to initiate discussion and influence direction from the first meeting onwards (Cox, 2004, p. 44). Upon its conclusion, members of an FLC formally evaluate its success with regard to meeting its initial objectives. Applicable types of assessment, such as surveys, provide reliable feedback and a basis for improving the FLC model (Beach, Clarke, \& Hubball, 2004).

\section{Implementation at the FoN}

In the past three years, the authors implemented six topic-based FLCs and one cohortbased FLC according to the community-building principles, such as being supported in achieving scholarly outcomes, described by Cox and Richlin (2004). For the topic-based FLCs, an open invitation to all faculty members, regardless of rank or employment contract, was offered. The majority of those who responded to the invitation were term-contract faculty. This was not surprising because over half of the faculty are in non-tenure track positions. As a group, they are diverse and have differing professional development needs and varying levels of loyalty and expertise (Barnshaw \& Dunietz, 2015). Yet they are all expected to provide consistently high levels of teaching to students (Dolan, Hall, Karlsson, \& Martinak, 2013). The membership in the FLCs ranged from seven to nine faculty members. For the cohort-based FLC, an invitation was sent to all new pre-tenure first-year faculty.

At the initial meeting of each FLC, the facilitator emphasized the importance of respect, confidentiality, and mutual support strategies. A facilitator can be a current member of the faculty, emerita, or externally hired to manage the logistics of FLC meetings and to move the group members towards mutuality and collaboration. Within the FLC, the facilitator maintains 
focus, monitors tasks, and supports the development of positive relationships. Personal problems, gossip, conflicts within the faculty, or other matters not related to community goals were discouraged, as all conversations were to be constructive. Nevertheless, the facilitator periodically had to remind participants to stay on task. Participants were provided with the seminal article by Cox (2004) to review so they could understand the theory and history of FLCs. As well, each FLC had a teaching assistant who kept detailed minutes of the meeting. The role of the teaching assistant proved invaluable for maintaining efficiency by supplying the previous meetings' minutes, recording the organic growth of the group discourse, and sharpening its focus.

Effective facilitation includes creative procurement of resources to be able to deliver FLCs. One of us used a teaching and learning research grant to pay for supplies, guest speaker honoraria, and refreshments served during the meetings. As facilitators, we were conscious of members' feelings and personalities, noted themes that arose, and provided summaries. In cases where unanimity was lacking - such as an issue or a goal that interested only some membersthe facilitator had to manage contentious emotions while being sensitive to diverse needs.

Early in the FLC process, members determined a name for their group as a means of promoting identity, solidarity, and mutuality. Naming also provided an opportunity for participants to indulge their lyrical or whimsical sides, as evinced by the names chosen such as "Swimming With the Dolphins", "Respectfully Yours", "Supernovas", and "Walking the Caring Path". Food provided at the meetings helped to establish a comfortable, friendly, and intimate atmosphere. This, in turn, fostered more creative and earnest dialogue.

\section{Evaluation}

All participants in the topic-based FLC completed pre- and post-FLC assessments using Cox and Richlin's (2004) model, wherein participants ranked various values from most to least important. It proved tedious and difficult to analyze; therefore, all subsequent FLC participants were sent a simple survey at the beginning of the FLC and were asked about their expectations, concerns, and hopes. At the end of the FLC, they were asked to provide recommendations for future FLCs and to describe the value of the FLC.

\section{Lessons Learned}

Participants recommended increased discussion time, clarity of expectations, and commitment to staying on task, as well as the determination of outcomes earlier in the process. Concerning the latter, for some FLCs, the time it took to choose the outcomes also contributed to developing skills in conflict resolution. In the post-FLC assessment, participants indicated the FLC process was rewarding, safe, respectful, candid, inclusive, and inspirational. It was an opportunity to reflect on teaching practices and an invaluable form of scholarship with positive effects on job satisfaction and collegial relationships.

Scheduling was the most challenging aspect of implementation across all the FLCs. The authors employed two scheduling strategies: on a week-to-week basis and predetermined dates over an entire term using Doodle, an online scheduling tool. In both instances, the original timelines were abandoned owing to the unpredictability of individual commitments and the time demands linked to teaching in the clinical areas. Some participants experienced frustration and discouragement from the frequent absences of a few colleagues, which impeded the discursive and consensual aspects of the process, as well as delaying key decisions regarding the scholarly 
outcomes. In the spirit of inclusivity, members who withdrew without notice were copied on meeting minutes. Nonetheless, the authors recommend establishing a maximum number of absences beyond which membership in a FLC is suspended.

There is no formal incentive for faculty to attend a FLC. In fact, for faculty in the topicbased FLCs, the time to attend and work on the scholarly outcomes was more than they anticipated. Pre-tenure faculty viewed the cohort-based FLC as essential for mentoring, information exchange, and networking, and thus they made it a priority to attend. All appreciated having food at the FLCs.

The sustainability of FLCs is a concern. Ideally, they would eventually be led by a variety of senior faculty members. Only one FLC was led by two faculty members who had been in a previous FLC with the author. It was a large FLC, and it took more time than anticipated to decide on the scholarly outcomes, so the FLC continued meeting past the set eight meeting times. An additional challenge with this particular FLC was that the majority of participants were term-contract faculty and were not paid to attend the FLC after their teaching contracts expired.

FLCs should meet eight times and have 8-12 members to function as an effective group (Cox, 2004). Some members so enjoyed the experience, they wanted to continue meeting with the facilitators. From the facilitators' perspective, this was not feasible given they had a number of FLCs. Thus, the time boundary of eight sessions proved invaluable. As for the number of members, one FLC was reduced to three members plus the facilitator and teaching assistant, yet the decision was made to keep meeting. The topic for this FLC was arts-based teaching and learning. This small group presented at a conference and wrote two chapters in a book demonstrating that, in fact, a group of five constituted a worthwhile FLC. The cohort pre-tenure group started with 11 members and increased to 13 as new faculty were hired. This FLC was very different in tone because the members wanted to start preparing for tenure as soon as they could, and the scholarly outcomes were their actual tenure submission.

The outcomes from FLCs included presentations, articles, letters, theatrical performances, books, faculty modules, briefs, and paintings. These outcomes tapped into the imagination, talent, passion, potential, and creativity of the participants. At a year-end meeting attended by all FLC participants and FoN administration, each FLC shared its experience of the FLC process and outcomes and made recommendations to the administration based on their findings. This meeting provided closure for participants and a transparent account of the FLC initiative for the benefit of the administrators.

\section{Conclusion}

FLCs are an efficient and engaging means of promoting teaching and learning scholarship amongst faculty members. The strength of a FLC is directly tied to the investment of its members and expert facilitation. The expectation that there be scholarly outcomes for the topic-based FLC raised the level of function and provided clarity of purpose within the FLCs. A hallmark of any effective and engaging faculty development event is that, when it is over, participants wish it could continue and leave wanting more. In our experience, this has been a consistent response to FLCs within our faculty of nursing. 


\section{References}

Anderson, J. R., Bond, B., Davis-Street, J., Gentlewarrior, S., Savas, M., \& Sheney, D. (2014). Transforming the classroom - and the world: Voices from a culturally inclusive pedagogy faculty learning community. Transformative Dialogues: Teaching and learning Journal, 7(1), 1-18.

Banasik, M. J., \& Dean, J. L., (2016). Non-tenure track faculty and learning communities: Bridging the divide to enhance teaching quality. Innovations in Higher Education, 41, 333-242. https://doi.org/10.1007/s10755-015-9351-6

Barnshaw, J., \& Dunietz, S. (2015). Busting the myths: The annual report on the economic status of the profession, 2014-2015. Academe, 101(2), 4-19.

Beach, A. L., Clarke, A., \& Hubball, H. (2004). Assessing faculty learning communities. In M. D. Cox \& L. Richling (Eds.), Building faculty learning communities (pp. 87-100). San Francisco, CA: Jossey-Bass.

Bond, N. (2015). Developing a faculty learning community for non tenure professors. International Journal of Higher Education, 4(4) 1-12. https://doi.org/10.5430/ijhe.v4n4p1

Brydes, S., Chilukuri, L., Cook, G., Feeley, M., Tour, E., \& Van Den Eide, L. (2012). Building a faculty learning community at a research university. Currents in Teaching and Learning, $5(1 \& 2), 17-35$.

Cox, M. D. (2004). Introduction to faculty learning communities. In Cox, M. D., \& Richlin, L. Editor (Eds.), Building faculty learning communities (pp. 5-24). San Francisco, CA: Jossey-Bass.

Cox, M. D. (2013). The impact of communities of practice in support of early-stage academics. International Journal for Academic Development, 18(1), 18-30. https://doi.org/10.1080/1360144x.2011.599600

Cox, M. D., \& Richlin, L. (Eds.). (2004). Building faculty learning communities. San Francisco, CA: Jossey-Bass.

Davidson, S. J. (2011). The experiences of novice nursing faculty: A complexity perspective (Doctoral dissertation, University of Alberta, Edmonton, AB). Retrieved from ProQuest Dissertations and Theses database (UMI: 992876092).

Dewey, J. (1916). Democracy and education. New York, NY: The Macmillan Company.

Dolan, D. M., Hall. M. S., Karlsson, C. R., \& Martinak, M. L. (2013). Five years later: Maryland adjuncts tell us (again) who they are and what they want. The Journal of Continuing Higher Education, 61(1), 35-45. https://doi.org/10.1080/07377363.2013.758552

Furco, A., \& Moely, B. E. (2012). Using learning communities to build faculty support ofr pedagogical iovation: A multi-campus study. The Journal of Higher Education, 83(1), 128-153. https://doi.org/10.1353/jhe.2012.0006

Gordon, L., \& Foutz, T. (2015). Navigating the first-year program: Exploring new waters in a faculty learning community. International Journal of Teaching and Learning in Higher Education, 27(1), 81-93. 
Kuznekoff, J. H., \& Titsworth, S. (2013). The impact of mobile phone usage on student learning. Communication Education, 62(3), 233-252. https://doi.org/10.1080/03634523.2013.767917

O'Meara, K. (2007). Stepping up: How one faculty learning community influenced faculty members' understanding and use of active learning methods and course design. Journal on Excellence in College Teaching, 18(2), 97-118.

Senge, P. M. (1990). The fifth discipline. New York, NY: Doubleday.

Wenger, E., McDermott, R. A., \& Snyder, W. (2002). Cultivating communities of practice: A guide to managing knowledge. Boston, MA: Harvard Business School Press.

Wicks, D. A., Craft, B. B., Mason, G., Gritter, K., \& Boldoing, K. (2015). An investigation into the community of enquiry of blended classrooms by a faculty learning community. Internet and Higher Education, 25, 53-62. https://doi.org/10.1016/j.iheduc.2014.12.001 